\title{
Rising Myanmar: US involvement, power rivalry and new hopes for Bangladesh
}

\author{
Ishtiaque Alam
}

The author wishes to acknowledge the remarks of two anonymous reviewers from CIRR for their insightful comments and suggestions.

\section{Abstract}

President Obama's symbolic and landmark visit to Myanmar bolsters the U.S. policy shift in Asia; an extremely significant step to firm up his Asia-Pacific policy, often described as a "pivot" to the region. Analysts have termed this visit a perfect fit in the larger geopolitical chess game by the Obama administration, which has sought to counter rising Chinese assertiveness by engaging its neighbours. With the transfer of power from an authoritarian government to a civilian one in March 2011, Myanmar embarked on a slow political liberalization. As Myanmar emerges from decades of isolation it generates much hope for the global and regional communities. Being the only other neighbour of Bangladesh besides India, Myanmar can usher new hope and possibilities for Bangladesh since both countries have outstanding issues. This article briefly tries to assess the underlying setting of the U.S. policy shift in greater Southeast Asia and particularly in Myanmar, the significance of this visit, how the other contenders of influence eye this increasing U.S. involvement, and finally the benefits it may yield for its neighbours, especially Bangladesh.

\section{KEY WORDS:}

Policy shift, contenders of influence, geopolitics, Bangladesh 
When, in 2009, President Barack Obama took office he inherited a wide array of overwhelming foreign policy challenges: an out-of-control war in Afghanistan, an impaired counterterrorism partnership with Pakistan, instability in Iraq, a potent threat from Al-Qaeda, a fragile Israel-Palestine peace process, an arrogant nuclear Iran, a wrecked relationship with Russia, and an aggressive North Korea. Added to this was a severe financial predicament at home and abroad. Of the most significant ideals the United States uphold globally, one is promoting democracy, enabling people's representatives to come to power. Unfortunately, the state of U.S. democracy promotion is also in peril. Intervening in Iraq and Afghanistan was closely associated with the promotion of democracy, while these moves, in contrast, tarnished the American image as a promoter of people's power. The ramifications of this tarnished image were far-reaching: an international backlash against democracy promotion that included extremely high levels of suspicion about the democracy agenda in the Arab world, a greatly heightened reluctance on the part of European and other international democracy supporters to be associated with U.S. policies and programmes in this area, and a marked decline in U.S. public support for democracy promotion as a priority of U.S. foreign policy.'

It is in this context that President Obama, freshly re-elected for his second tenure, underscores his desire to reorient American foreign policy more toward the Asia-Pacific region; an extremely important step to firm up his Asia-Pacific policy, often described as a "pivot" to the region. ${ }^{2}$ President Obama announced in November 2011 his plan to 'rebalance' the U.S. position in the Asia-Pacific region. The core of this announcement was, as he said: "as President, I have therefore made a deliberate and strategic decision - as a Pacific nation, the United States will play a larger and long-term role in shaping this region and its future, by upholding core principles and in close partnership with allies and friends." ${ }^{3} \mathrm{He}$ continued:

Carothers, T. (2007). U.S. democracy promotion during and after Bush. Washington D.C: Carnegie Endowment for International Peace.

2 Chongkittavorn, K. (2012). Obama visit to firm up US policy on Asia, The Nation, 12 November.

3 Remarks by President Obama to the Australian Parliament (2011). http://www.whitehouse.gov/the-press- 
".... I have directed my national security team to make our presence and mission in the Asia-Pacific a top priority." The so-called "Obama Doctrine' was further elaborated, explained, redefined and strengthened by various visits of Secretary of State Hillary Clinton, Secretary of Defence Leon Panetta and other officials during their visit to Asia and interactions with the Asian leaders and policymakers. ${ }^{4}$ According to the White House announcement the newly re-elected President would head to an annual international economic summit meeting in Cambodia and stop in Thailand and Myanmar. No sitting American President has visited either Myanmar, formerly known as Burma, or Cambodia, allowing Mr. Obama to reinforce his commitment to the region. ${ }^{5}$ Some observers called it the beginning of the U.S. re-engagement in the Asia-Pacific region.

Now enthusiasts can rightly point out: why this renewed U.S. interest towards Southeast Asia in general and Myanmar in particular? What significance does this visit carry? How do other contenders of influence in this region view the U.S. engagement in Myanmar, and finally, what opportunities can this visit provide for Bangladesh and what considerations does Bangladesh need to assess in order to reap the benefits of harmonizing their bilateral relations?

\section{Southeast Asia in the U.S. geopolitical imagination}

Despite America's bad reputation in enmeshing itself in the Vietnam War, it has engaged with the Southeast Asian nations for the last 30 years. Southeast Asia is the third largest Asian trading partner of the U.S. after China and Japan, with a population of nearly 600 million and a combined economy of US $\$ 1.5$ trillion in 2008. It also attracts the largest amount of U.S. investment in Asia. Southeast Asia is the route for the U.S. from the Pacific to the Indian Ocean. Southeast Asian states are the littoral nations that border the South China Sea, sometimes labelled as the 'second Persian

4 Muni, S. D. (2012) Obama Administration's Pivot to Asia-Pacific and India's Role. ISAS Working Paper, No. 159, 29 August.

5 Baker, P. (2012). Obama to Visit Myanmar as Part of First Postelection Overseas Trip to Asia. The New York Times, 8 November. http://www.nytimes.com/2012/11/09/world/asia/obama-to-visit-myanmar.html (17 November 2012). 
Gulf' due to its potential for huge hydrocarbon reserves. But the U.S. primacy in Southeast Asia waned with the amazing rise of China. Tensions in U.S. China relations have thus had a considerable impact on the region, particularly in the maritime domain. Although each Southeast Asian state has developed its own set of bilateral relations with these major powers, individual states prefer not to choose between China and the United States, favouring instead a united approach through the Association of Southeast Asian Nations (ASEAN). ${ }^{6}$

U.S. interests in Southeast Asia can be categorized broadly into five key areas.' First, the U.S. tried to preserve a stable security order in this region together with alliances for keeping away any power, regional or extra-regional, from wielding supremacy. Second, the U.S. helps a liberal international economic order to be promoted in the region. Third, big economic assistance programmes were encouraged from Washington to advance economic development. Fourth, this region was regarded as optimal ground for the U.S. for promoting its cherished ideals of democracy, human rights, rule of law and religious freedom. Last but not least, Southeast Asia's terrorist groups were specifically targeted as part of the global war on terrorism that the U.S. had taken up after the terrorist attacks of September 11. But more than any of these overarching interests, the rise of China and the increasing positive influence wielded by ASEAN prompted the U.S. to magnify its presence in this region and recalibrate its Asia policy.

\section{Why visit Myanmar?}

Shortly after his re-election, President Obama announced his desire to head an annual international economic summit meeting in Cambodia with stops in Thailand and Myanmar. His stop in Myanmar was a historic one since no U.S. President has ever visited Myanmar, a state infamous for authoritarianism. Prior to his Myanmar visit announcement Secretary of

6 Thayer, Carlyle A. (2012). The Rise of China and India: Challenging or Reinforcing Southeast Asia's Autonomy? Strategic Asia 201 1-2012. Seattle and Washington DC: NBR. 
State Hillary Rodham Clinton's visit to Myanmar represented a dramatic shift in policy towards Myanmar, an opening that demonstrates a new U.S. focus on Asia by building ties to a strategically important country bordering China. ${ }^{8}$

Analysts have termed this visit a perfect fit into the larger geopolitical chess game by the Obama administration, which has sought to counter rising Chinese assertiveness by engaging its neighbours. China was Myanmar's chief international patron during the final years of military rule there, and the long-isolated country's opening to the West comes amid a popular backlash against Beijing's perceived influence and its role in extracting natural resources. ${ }^{9}$ The U.S. also wants to strengthen its ties with Myanmar for the reason that the relationship gap between the U.S. and Myanmar is too wide because the various sanctions imposed by the U.S. and other Western countries on Myanmar and China, astutely, have taken the benefit of this prolonged absence of Western states to consolidate their footing in virtually all sectors of Myanmar polity.

Nonetheless, one should not forget the unique strategic geographical setting that Myanmar enjoys. Distinctively positioned between India and China, Myanmar's large coastline grants naval access to the Strait of Malacca, one of the world's most vital strategic water passages, and the shortest sea route between the Persian Gulf and China. It is the key choke point in Asia. Myanmar is also strategically important for China's 'string of pearls' hypothesis which is designed to counter U.S. control over the Strait of Malacca. The geopolitical map of Southeast Asia reveals that Myanmar is the strategic back door of China, a kind of soft spot underbelly. Perhaps this justifies China's incessant involvement with Myanmar.

Keeping aside geopolitical considerations, Myanmar is important for the U.S. on certain other grounds as well. Myanmar's internal deteriorated human rights scenario has always been at the forefront of U.S. concerns. America's sole desire is to shift power from the military regime to the victors of the 1990 election. There is also the potential for state collapse in Myanmar, which in turn will only add fuel to the fire in further deteriorating instability

8 Richter, P. and Magnier, M. (201 1). Hillary Clinton's Myanmar trip marks significant shift in policy. The Los Angeles Times, 30 November.

9 Baker, P. (2012). Obama to visit Myanmar as part of first postelection overseas trip to Asia. The New York Times, 8 November. 
to its neighbours. In the Failed States Index produced by Fund for Peace, Myanmar currently stands at number 21 as the only country from Southeast Asia, with Afghanistan at number 6 and Pakistan at number 13. ${ }^{10}$ Apart from state collapse, Myanmar's narcotic production and export has become an irritant for the U.S. as the U.S. is a major destination for these illegal drugs.

With Obama's visit to Myanmar the Myanmar government pledged to release an estimated 1,600 political prisoners, and up to November 2012 a total of 452 detainees had been freed. Observers also said that President Obama's visit will encourage Myanmar not to engage in any sort of military and nuclear trade with North Korea. U.S. Special Representative for North Korea Policy Glyn Davies remarked: "I think that Burma's on the right path, that they have made a strategic decision to fundamentally alter their relationship with the DPRK and to ultimately end these relationships with North Korea." "1 After Secretary of State Hillary Clinton's visit to Myanmar, Washington appears to have accepted 'strong assurance' from President Thein Sein that Myanmar will work with the International Atomic Energy Agency (IAEA) in abiding by its Additional Protocol. Once signed, this instrument should help settle the U.S. and international fears about the possibility of a Burmese nuclear programme.

Obama ended the long-standing U.S. isolation of Myanmar's generals, which has played a part in coaxing them into political reforms that have unfolded with surprising speed in the past few years. The U.S. has appointed a full ambassador and suspended sanctions to reward Myanmar for political prisoner releases and SuU Kyi's election to parliament. ${ }^{12}$ U.S. Secretary of State Hillary Clinton stated on November 14, 2012, that President Barack Obama would discuss the deadly sectarian violence in Myanmar's Rakhine State between Rohingya Muslims and Buddhists during his historic visit to the country, and Secretary Clinton said this unrest would "of course" feature in Obama's talks. ${ }^{13}$ In effect, President Obama, in his Yangon University speech, said: "Today, we look at the

10 Failed States Index 2012. htpp://www.fundforpeace.org/global/? $q=f s i 2012$ ( 18 November 2012).

11 Jones, T. Y. (2012). U.S. says Myanmar "on right track" over North Korea arms ties. Reuters, 22 October. hitp:// www.reuters.com/article/2012/10/22/us-korea-north-myanmar-idUSBRE89LOEM20121022 /18 November 2012).

12 Kuhnhenn, J. (2012). Obama to visit Myanmar, Cambodia, Thailand. Hastings Tribune, 10 November.

13 Obama to discuss Rohingya violence on Myanmar visit. http://au.news.yahoo.com/world/a/-/ world/15383578/obama-to-discuss-rohingya-violence-on-myanmar-visit/ (18 November 2012). 
recent violence in Rakhine State that has caused so much suffering, and we see the danger of continued tensions there. For too long, the people of this state, including ethnic Rakhines, have faced crushing poverty and persecution. But there is no excuse for violence against innocent people. And the Rohingya hold themselves - hold within themselves - the same dignity as you do, and I do."14

\section{India and China's scramble over Myanmar}

Myanmar is crucial for both India and China for a variety of reasons. India has its own set of priorities in dealing with Myanmar. Initially India was in favour of the pro-democracy movement in Myanmar after the 1990 election results were cancelled. But when Myanmar started to tilt toward China, India changed its diplomatic course as far as relations with Myanmar were concerned. However, this change of course resulted in U.S. President Barack Obama's rebuke to India that "the Indian establishment does not do enough to promote democracy in Myanmar". ${ }^{15}$ Broadly, India has five far-reaching interests in Myanmar.

Myanmar is India's land connection to the ASEAN region and the success of India's "Look East Policy" largely depends on closer relations between the two countries. India's troubled Northeastern part is still insurgency prone and many insurgents take shelter in Myanmar. ${ }^{16}$ Hence, closer ties between the two nations will help India to combat the anti-Indian elements across borders. India eyes Myanmar as a potential source of oil and a supplier of natural gas. As Myanmar is a neighbouring country of India, it will involve affordable transportation costs and risks to India compared to importing resources from distant sources. Another important consideration for India is that a deepening relation with Myanmar will help to reduce China's growing strategic footprint in India's neighbourhood.

14 Remarks by President Obama at the University of Yangon. http://www.whitehouse.gov/the-pressoffice/2012/11/19/remarks-president-obama-university-yangon (19 November 2012).

15 Borah, R. (2012). India's huge stakes in Myanmar. Russia and India Report, 23 April. http://indrus.in/ articles/2012/04/23/indias huge stakes in myanmar 15552.html (18 November 2012).

16 Insurgent groups using Myanmar territory: MHA. India Blooms. http://www.indiablooms.com/ NewsDetailsPage/2012/newsDetails280812cl.php (26 December 2012). 
Finally, Myanmar is crucial for India's land connectivity with the rest of the Southeast Asia region.

China primarily views Myanmar as a huge market for Chinese goods. China's relation with Myanmar is largely driven by its 'Go West' strategy started in 2000. Yunnan province in China is the nearest region to Myanmar. Between 1996 and 2005, the Myanmar-Yunnan border trade accounted for about 55 per cent of Myanmar's total trade value; and Myanmar is the largest trading partner of Yunnan. ${ }^{17}$ The China-Myanmar border trade has flourished in recent years. China's exports increased 3.1 times, from US $\$ 261.2$ million in 2001 to US $\$ 800.4$ million in $2007 . .^{18}$

For 60-70 per cent of its oil shipment China is heavily dependent on the Malacca Strait, a strategic waterway that connects the Persian Gulf with the South China Sea. For the security and safety of its oil shipment China has increased its presence in the region by developing special diplomatic and strategic relations with the littoral states of the Indian Ocean. ${ }^{19}$ China was eager to find a trading outlet to the Indian Ocean for its landlocked inland provinces of Yunnan and Sichuan, via Myanmar. The Myanmarese railheads of Myitkyina and Lashio in Northeastern Myanmar, as well as the Irrawaddy River, were potential conduits. China has provided Myanmar with generous government support and preferential loans. For the last decade, Myanmar has received economic assistance in the form of grants, interest-free loans, concessional loans or debt relief. China provides economic assistance to protect its own investment in the country and influences the junta and ethnic groups on their side to pursue economic trade with Myanmar. Since 1988, China has helped the Myanmar government build 8 out of 9 sugar mills [US $\$ 158$ million], 20 hydroelectric plants [US\$269 million], 13 out of 45 new factories for the Ministry of Industry-1 [US $\$ 198$ million], and 12 out of 21 new plants for the Ministry of Industry-2 [US\$137 million]. Also, China upgraded 6 factories for the Ministry of Industry-2 [US\$346 million], provided 6 ocean-going vessels, and built a dry dockyard [US $\$ 25$ million]. In 2006, Chinese firms built seven

17 Myoe, M. A. (2007). Sino-Myanmar economic relations since 1988. Asia Research Institute Working Paper, No. 86. $w$ ww. ari.nus.edu.sg/showfile. asp? pubid $=647 \&$ type $=2$ ( 18 November 2012).

18 Kudo, T. (2008). Myanmar's Economic Relations with China: Who Benefits and Who Pays? in Monique Skidmore and Trevor Wilson (eds.) Dictatorship, Disorder and Decline in Myanmar. Canberra: Australian National University. pp. 87-101. 
out of eleven new hydroelectric plants [US \$ 350-400 million]. ${ }^{20}$ Intelligence analysts often say that China's economic, political and military influence in the country has already become so strong that it would be hard for Yangon to radically reorient its foreign policy. ${ }^{21}$

\section{What changes can we expect?}

Against this backdrop, what changes can Obama's visit bring in the already prevailing power calculus? Chinese Vice Foreign Minister Fu Ying reiterated that "China didn't see as a threat Mr. Obama's planned visit to Myanmar, as part of a regional visit. We believe the U.S. is not here to threaten China, and China has no intention to pose a threat to the U.S.". ${ }^{22}$ But there is considerable hype among the media that President Obama's historic visit is rooted in a strategic edge to shape new relationships as part of a larger 'shadow-boxing match' with China over influence in the region. ${ }^{23}$ President Obama's trip to Asia, which includes visits to Thailand and Cambodia, comes in the immediate wake of a change in China's top leadership, which has added an element of uncertainty to relations between the superpowers. For President Obama, the trip represents a fresh effort to make good his promise to shift U.S. attention towards Asia. The Asia trip underscores Obama's efforts to establish the United States as an Asia-Pacific power, a world view defined by 21 st century geopolitics but also by Obama's personal identity as America's first Pacific President. ${ }^{24}$

20 This part of the literature is entirely drawn from Tea, B. (2010). China and Myanmar: Strategic interests, strategies and the road ahead. IPCS Research Paper 26, September.

21 China's ambitions in Myanmar. hitp://www.asiapacificms.com/articles/myanmar_influence/ 18 November 2012).

22 Tejada, C. (2012). China not concerned with Obama's visit to Myanmar. The Wall Street Journal, 16 November. http://online.wsi.com/article/SB 10001424127887324735104578123992776767714. html (1 8 November 2012).

23 Meckler, L. (2012). Obama's Asia trip comes amid tug of war with China. The Wall Street Journal, 16 November. http://online.wsi.com/article/SB 10001424127887324735104578123360564992242. html? mod=rss most viewed day asia?mod=WSIAsia article forsub (18 November 2012)

24 Obama's visit to Myanmar offers a chance to reinforce American influence in Asia. http://www.cleveland.com/ nation/index.ssf/2012/11/obamas_visit_to_myanmar_offers.html (18 November 2012). 
The countries President Obama visited, Thailand, Myanmar and Cambodia, have long been considered Beijing-friendly neighbours. His immediate post-election tour to these countries inevitably fuelled anxiety to China, at least partially if not completely, and it is not unusual for Beijing to think of these visits' aim as diminishing Beijing's regional influence.

China observed President Obama's visit to Myanmar most cautiously. There are certain obvious reasons for this vigilance. The U.S. engagement in Myanmar is now in an evolutionary phase and how fast the U.S. acts to eliminate sanctions and promote FDI concerns China. China is mindful about the upcoming completion of the dual gas and oil pipelines across Myanmar from the Indian Ocean to Yunnan province in China which is likely to be completed by 2013. China does not want any kind of obstacles to impede the construction of the pipelines. China is deeply concerned about the suspended construction of the Myitsone dam, a large hydroelectric power dam on the Irawaddy River in Myanmar, which is supposed to export electricity to China. Pressure from the United States might persuade Thein Sein's government-supported by Aung San Suu Kyi's opposition party- to terminate not only this project but other hydroelectric dams that China wants Myanmar to build. Since President Thein Sein's inauguration in March 201 1, Myanmar has jumped from a pro-China tilt to an ostensibly non-aligned position vis-à-vis the world's superpowers. Any further movement by Myanmar away from China and toward the United States during Obama's visit will ring alarm bells in Beijing. ${ }^{25}$ However, the good news is that not only China and the U.S. but also other regional powers including India share common beliefs that a stable and prosperous Myanmar will benefit all countries. Evidence suggests that China has even encouraged Myanmar to ease strains with the U.S. to boost economic progress. ${ }^{26}$

25 Reiffel, L. and Sun, Y. (2012). Obama in Burma. Brookings Opinion. 16 November. hitp://www.brookings.edu/ research/opinions/2012/11/16-obama-burma-ieffel-sun (1 8 November 2012)

26 Selth, A. (2012). United States relations with Burma: From hostility to hope. Regional Outlook Paper No. 36. Australia: Griffith Asia Institute. 


\section{India as the trump card}

Over the years China has ensured impressive economic growth not just in terms of monetary sense but also in the political and military arena. China has increased its defence spending, second highest after the U.S., with the ascent of its economy and a cautious eye on the Obama administration's focus on the Asia-Pacific region. China has spats with Vietnam, the Philippines and Japan over oil and gas resources in the South China Sea, and with India it has territorial disagreement. According to the Stockholm International Peace Research Institute, China increased its defence budget for 2012 by $11.2 \%$ to 670.3 billion Yuan. ${ }^{27}$ Wary of China's growing economic and military muscle flex, many of the countries of Southeast Asia have started to court India as their trump card against China. Proof of this argument can be found in the high-level visit of Myanmar's President $U$ Thein Sein and Vietnam's President Truong Tan Sang to India as an acknowledgement of India's role as a strategic balance keeper. India has also endorsed this unique opportunity to augment its national interest in Southeast Asia as part of her larger Look East policy. India is becoming a critical player in this evolving balance of power. Singapore's founding father Lee Kuan Yew sees India as "part of the Southeast Asia balance of forces" and "a counterweight [to China] in the Indian Ocean." 28 More blatantly, India's role as a strategic balance keeper was seen when India lined up with Vietnam against China's opposition to the exploration of energy by India's state-owned oil and gas firm in the South China Sea. This display of standing for each other improved India's place in the Southeast Asia region. In addition, naval cooperation between India and Vietnam is heightening. Vietnam has given India the right to use its port in the south, Nha Trang, situated close to the strategically significant Cam Ranh Bay. The Burmese President showed an interest in expanding cooperation in oil and gas exploration, opening border trade, and speeding up the construction of natural gas pipelines with greater Indian investment in Myanmar's energy sector. Seeing all these avenues of benefits, India remains opposed to Western sanctions on the country. Myanmar's recent

27 China increases defence budget for 2012 by $11.2 \%$ to 670.3 billion Yuan. http://www.sipri.org/media/expertcomments/expl (5 April 2013).

28 China and India cannot go to war: Lee Kuan Yew. http://www.thehindu.com/news/china-and-india-cannot-go-towar-lee-kuan-yew/article 1119062 .ece (5 April 2013). 
moves towards democratic transition will give India a larger strategic space to manoeuvre, and compared to Beijing, New Delhi will be a more attractive partner for Burma. Hence, it is comprehensible why India has so much interest in promoting its Look East policy with such vigour in Southeast Asia.

\section{Significance of Bangladesh-Myanmar relations}

Of the three forms of relations between countries - conflictual, collaborative and competitive - Bangladesh-Myanmar relations have evolved through phases of cooperation and conflict; conflict not in terms of confrontation, but in terms of conflict of interests and a resultant diplomatic face-off. Being the only other neighbour besides India, this can provide certain strategic advantages for Bangladesh. It is the potential gateway for an alternative land route opening towards China and Southeast Asia other than the sea. This road link has the potentiality for a greater communication network between Bangladesh and Southeast Asian countries including Thailand, Malaysia and Singapore. Moreover, with a rich natural resource base, Myanmar is a country with considerable potential. Myanmar's forests and other natural resources like gas, oil and stones from which Bangladesh can benefit greatly are enormous. For this reason, it is more in Bangladesh's interest to maintain good relations with Myanmar for reasons of national security. Unfriendly relations with Myanmar can benefit small insurgent groups living in the hilly jungle areas of the southern portion of the Chittagong Hill Tracts which can cause some degree of instability in the area and become a serious concern for national security. ${ }^{29}$ With the amicable resolution of the maritime boundary issue, the single biggest irritant between Bangladesh and Myanmar remains the Rohingya refugees. Bangladesh has high hopes that with the amelioration of internal conditions within Myanmar this outstanding issue will also be solved one day. 


\section{Bangladesh's stake in ASEAN}

Myanmar's importance to Bangladesh is threefold: Bangladesh's internal peace and security can largely be ensured through harmonious relations with Myanmar; it provides immense opportunities to foster relationships with the greater Southeast Asian region; and finally, Myanmar gives the opportunity to Bangladesh to collaborate more closely with ASEAN and the ASEAN Regional Forum (ARF). Bangladesh joined the ARF in 2006. Bangladesh needs to be an effective dialogue partner of the ARF. Bangladesh's unique geographical location marks a natural bridge between South and Southeast Asia. Bangladesh needs to be ready to support all initiatives and efforts to sustain and strengthen bilateral ties in every possible direction. Bangladesh has generally admired the success of ASEAN, especially in comparison to SAARC, and should follow, in some way or another, the steps taken by ASEAN countries towards building infrastructure, poverty alleviation, tourism and overall regionalism, though SAARC has been in existence for a much shorter period. ${ }^{30}$ Bangladesh shares a common historical and cultural heritage with the ASEAN nations. Its overall economic and social indicators are not bad compared to those of the new members of ASEAN. Bangladesh's economy is almost equal to the size of the combined economies of the new members of ASEAN and so is the size of its population. Moreover, the country links Southeast Asia with the comparatively vast market of South Asia. Myanmar has already been accepted as an observer to SAARC and Myanmar has pledged to support Bangladesh for her increased engagement to ASEAN. Against this backdrop, Bangladesh has much to gain from Myanmar's increased support with respect to ASEAN and Myanmar can gain similar benefits from Bangladesh with respect to SAARC. The greatest motivation for Bangladesh to maintain friendly and collaborative relations with Myanmar is that the majority of the exports (on average 86\%) of Bangladesh has occurred with EU and NAFTA countries, but this is risky due to uncertain problems related to exporting to these countries and our dependency on them, which may cause serious damage to our economy. So, improving trade performance with Eastern countries, especially with ASEAN countries, can reduce the dependency on exporting to the West. ${ }^{31}$

30 Shyla, Shawon, ASEAN Regional Forum (ARF): What can Bangladesh expect from this security platform? hitp:// www.bipss.org.bd/images/Focus-ARF(1).pdf (5 April 2013).

31 Alom, Md. Morshed (2005). Bangladesh's Engagement with ASEAN: Retrospect and Prospect. SEA Thesis Research, Students' Theses, MA in Southeast Asian Studies, Chulalongkorn University. http://www.seachula. com/ books.htm 


\section{Concerns for Bangladesh}

With the transfer of power from an authoritarian government to a civilian one in March 2011 , Myanmar embarked on a slow political liberalization. President Thein Sein, a former military general, kicked off long-expected reforms: over 700 political prisoners were released in October 2011 and January 2012. The country's strict media regulations were relaxed. The government also relaxed internal censorship laws and unblocked the websites of exiled radio and TV stations (Democratic Voice of Burma, Voice of America). ${ }^{32}$ With these reforms Myanmar has elevated its position in the international arena. As Myanmar emerges from decades of isolation it generates much hope for global and regional communities.

With regard to Bangladesh, Myanmar is one of only two neighbours. Bangladesh is overburdened with Rohingya refugees who fled from Myanmar for fear of persecution. Despite Bangladesh's lengthy efforts to send these refugees back to Myanmar, Yangon did not pay much heed to taking these people back. But it is important to keep in mind that many matters are ostensibly more difficult under a military government than under a civilian one. As positive changes begin to take place in Myanmar, Bangladesh should take full benefit from these much expected changes. Bangladesh and Myanmar have, among others, two longstanding unsolved issues, and one of them, the maritime boundary demarcation, was resolved peacefully in March 2012 by the International Tribunal for the Law of the Sea (ITLOS)..$^{33}$ Thus, the only remaining issue is the repatriation of the Rohingya refugees. President Obama's November 19, 2012 visit focused some light on the reconciliation of this problem. President Obama's iteration and emphasis on resolving the Rohingya issue put pressure on part of the Myanmar government to take reconciliatory measures to settle this subject. Hence, it is high time for Bangladesh to vigorously pursue all its diplomatic strings to move forward in clearing up the matter. But, very recently Suu Kyi, Myanmar's iconic pro-democracy leader, commented that the recent violence in West Myanmar between

32 Bünte, M. and Portela, C. (2012). Myanmar: The beginning of reforms and the end of sanctions. GIGA Focus, No. 3. Hamburg.

33 The verdict can be found in http://www.itlos.org/fileadmin/itlos/documents/cases/case_no_16/1-C16 
Buddhists and Muslims was a "huge international tragedy", and he said that "illegal immigration from Bangladesh had to be stopped otherwise there will never be an end to the problem". ${ }^{4}$ The Bangladesh Foreign Ministry expressed sheer "surprise at such comments since these are clearly at variance from the position of the Myanmar Government and the action taken by them to resolve the issue over the last several years". 35 This comment from a much respected personality worldwide reaffirms that Bangladesh needs to work not just with the government of Myanmar but also with Aung Sun Suu Kyi to bring the resolving of the refugee issue to an acceptable solution.

President Obama's visit will also likely usher in a gradual lift of all sanctions and has also enabled international financial institutions like the World Bank to engage in development works in Myanmar. As of November 2, 2012 the World Bank allocated US\$245 million in credit and grant funding for Myanmar under an 18-month work plan, the first lending in 25 years. The Bank also approved an US\$80 million grant for community-driven rural projects. ${ }^{36}$ This means that Myanmar is opening for foreign business and big U.S. companies - including GE and Coca-Cola - have already returned to start business in Myanmar. Bangladesh can and should take this opportunity to expand its business to Myanmar. The volume of Bangladesh-Myanmar border trade was around US\$23 million in the 2011 2012 fiscal year (FY). ${ }^{37}$ Data from the commerce ministry show that in the 2010-11 fiscal year Bangladesh imported goods worth US $\$ 179$ million and exported goods worth US\$9.65 million. Data also show that in the 20092010 fiscal year Bangladesh imported goods worth US $\$ 69.61$ million and exported goods worth US $\$ 10.04$ million. ${ }^{38}$ The trade gap was in Myanmar's favour until the last FY and the gap is expected to be narrowed down as Myanmar started to import some new materials from Bangladesh from early 2012, following the visit of Bangladesh Prime Minister Sheikh Hasina to Yangon in late 2011 . Myanmar has added cement, medicine, biscuits, iron, tin and soft drinks to the import list. Bangladesh also exports steel

34 Bangladesh dismisses Suu Kyi comments on Rohingya. http://sg.news.yahoo.com/bangladesh-dismisses-suu-kyicomments-rohingya-162708 166.html ( 18 November 2012).

35 Press Release, Dhaka, 18 November 2012, Ministry of Foreign Affairs, Bangladesh. http://mofa.gov.bd/index. php?option=com_content\&view $=$ article\&id $=168 \&$ catid=43\&PRid=635 (1 8 November 2012).

36 Rashid, Barrister H. (2012). Obama's symbolic visit to Myanmar. The Daily Star. 17 November.

37 Myanmar-Bangladesh border trade still not active. http://www.elevenmyanmar.com/business/73-myanmarbangladesh-border-trade-still-not-active (1 8 November 2012).

38 Mirdha, R. (2012). Regional trade: Moving Towards Change. Forum, Vol. 6, Issue 9, September. The Daily Star. 
products, light engineering machinery, cement, dry foods and cosmetics to Myanmar. ${ }^{39}$ Bangladesh can import energy from Myanmar and export ready-made garments, pharmaceutical products, knitwear, jute and jute goods, and ceramics to Myanmar at competitive prices. Bangladesh's decision to organize a "Single Country Trade Fair" in Yangon is a welcome decision in this regard. Thus, there is immense opportunity for Bangladesh to reap commercial benefits from a newly open Myanmar.

President Obama's visit to Myanmar represents a high degree of 'symbolism'. With his visit the EU is also planning to reconsider the possible removal of sanctions imposed earlier on Myanmar. Thus, it will not be surprising if other Western and European nations show interest in investing in Myanmar. Bangladesh should take calculated and prudent decisions to expand its business coverage in Myanmar keeping in mind its larger Look East policy.

Bangladesh must win over the negative perception that prevails among the people of Myanmar and should portray that Myanmar has much to gain from Bangladesh. Bangladesh's extended maritime frontier, along with the future plan of constructing a deep-sea port at Sonadia Island, ${ }^{40}$ will make this region a regional hub and its benefits will be available to all other Asian countries, let alone Myanmar. Of course, connectivity via land, sea and air must have priority but that does not, by any means, imply that there should be less people-to-people contact between the two countries. On the contrary, mutual interactions should get a boost through various cultural exchanges, sports, education programmes, trade fairs, and other mutually beneficial activities. ${ }^{41}$ Fine-tuning bilateral relations between Bangladesh and Myanmar will only bring common good to the entire region. The reforms that Myanmar is currently undergoing are praiseworthy and upon their success depends much of the prospect of stability and development in the region. National reconciliation in Myanmar contributes to the strengthening of border areas and could help ameliorate the nontraditional security challenges originating from Myanmar. ${ }^{42}$

39 Ahmed, N. (2012). Bangladesh-Myanmar border trade resumes after three months. The Financial Express, 5 September.

40 Bangladesh pins hope on Chittagong port. BBC News. http://www.bbc.co.uk/news/business-19462142 (27 December 2012).

41 Aziz, A. H. (201 1). Recalibrating Bangladesh-Myanmar relation. The Daily Star. 17 December. 


\section{Concluding thoughts}

Myanmar is a country of far-reaching significance for many countries. Situated in a unique geographic juncture it has much to offer to its immediate and distant neighbours. With the amelioration of the internal governance situation in Myanmar, hopes are high that the country will now embark on a journey towards democratic principles. Now, the Myanmar government is collaborating with the iconic pro-democracy leader Aung Sung Suu Kyi. Recently, SuU Kyi visited India for six days, from 13th to 18th November 2012, at the invitation of Sonia Gandhi. As Myanmar goes through a major transition domestically, the Indian government is acutely aware that SuU Kyi and her party may likely play an increasingly important role in her country. The United States is also very sanguine about Myanmar's journey towards democratic reforms. President Obama's visit to Myanmar and his historic speech at Yangon University ushered in hopes for not only the USA and India but also for European countries as well as Myanmar's immediate and distant neighbours. This has marked a significant display of policy shift by the Western nations which was sparked by Secretary of State Hillary Clinton's visit to Myanmar. Almost all the countries, except a wary China, which wish to nurture relations with Myanmar are optimistic about Myanmar's transition to progress. Myanmar is utilizing this transition to harness external support on the one hand and balance its relation with China. An inquisitive India and wary China have set the scene for a scramble over Myanmar. Amidst this improved situation Bangladesh should and needs to take a pragmatic and timely approach to recalibrating its relations with Myanmar. Keeping in mind the larger interests of Bangladesh in Southeast Asia, in ASEAN and the ARF, Bangladesh should rally its full support in favour of Myanmar's much expected reforms by courting the international community and devising calculated plans to move further with an extended hand. There is no denying the fact that a more open and stable Myanmar presents the greatest opportunity to strengthen bilateral relations in an amicable manner. 


\section{B Bibliography}

Ahmed, N. (2012). Bangladesh-Myanmar border trade resumes after three months. The Financial Express, 5 September.

Alom, Md. Morshed (2005). Bangladesh's Engagement with ASEAN: Retrospect and Prospect. SEA Thesis.

Aziz, A. H. (2011). Recalibrating Bangladesh-Myanmar relation. The Daily Star. 17 December.

Baker, P. (2012). Obama to visit Myanmar as part of first postelection overseas trip to Asia. The New York Times, 8 November.

Bünte, M. and Portela, C. (2012). Myanmar: The beginning of reforms and the end of sanctions. GIGA Focus, No. 3. Hamburg.

Carothers, T. (2007). U.S. democracy promotion during and after Bush. Washington D.C: Carnegie Endowment for International Peace.

Chongkittavorn, K. (2012). Obama visit to firm up US policy on Asia, The Nation, 12 November.

Gong, L. (2012). Implications of national reconciliation in Myanmar. NTS Alert. March.

International Crisis Group (2009). China's Myanmar Dilemma. Asia Report No.177, 14 September.

Kudo, T. (2008). Myanmar's Economic Relations with China: Who Benefits and Who Pays? in Monique Skidmore and Trevor Wilson (eds.) Dictatorship, Disorder and Decline in Myanmar. Canberra: Australian National University. pp. 87-101.

Mirdha, R. (2012). Regional trade: Moving Towards Change. Forum, Vol. 6, Issue 9, September. The Daily Star.

Muni, S. D. (2012) Obama Administration's Pivot to Asia-Pacific and India's Role. ISAS Working Paper, No. 159, 29 August.

Rashid, Barrister H. (2012). Obama's symbolic visit to Myanmar. The Daily Star. 17 November. 
Richter, P. and Magnier, M. (2011). Hillary Clinton's Myanmar trip marks significant shift in policy. The Los Angeles Times, 30 November.

Selth, A. (2012). United States relations with Burma: From hostility to hope. Regional Outlook Paper No. 36. Australia: Griffith Asia Institute.

Thayer, Carlyle A. (2012). The Rise of China and India: Challenging or Reinforcing Southeast Asia's Autonomy? Strategic Asia 2011-2012. Seattle and Washington DC: NBR.

This part of the literature is entirely drawn from Tea, B. (2010). China and Myanmar: Strategic interests, strategies and the road ahead. IPCS Research Paper 26, September.

\section{Web sources:}

Remarks by President Obama to the Australian Parliament (2011). http:// www.whitehouse.gov/the-press-office/2011/11/17/remarkspresident-obama-australian-parliament (17 November 2012).

Baker, P. (2012). Obama to Visit Myanmar as Part of First Postelection Overseas Trip to Asia. The New York Times, 8 November. http://www. nytimes.com/2012/11/09/world/asia/obama-to-visit-myanmar. html (17 November 2012).

Failed States Index 2012. http://www.fundforpeace.org/global/? q=fsi2012 (18 November 2012).

Jones, T. Y. (2012). U.S. says Myanmar "on right track" over North Korea arms ties. Reuters, 22 October. http://www.reuters.com/article/2012/10/22/uskorea-north-myanmar-idUSBRE89LOEM20121022 (18 November 2012).

Kuhnhenn, J. (2012). Obama to visit Myanmar, Cambodia, Thailand. Hastings Tribune, 10 November.

Obama to discuss Rohingya violence on Myanmar visit. http://au.news. yahoo.com/world/a/-/world/15383578/obama-to-discussrohingya-violence-on-myanmar-visit/ (18 November 2012).

Remarks by President Obama at the University of Yangon. http://www. whitehouse.gov/the-press-office/2012/11/19/remarks-presidentobama-university-yangon (19 November 2012). 
Borah, R. (2012). India's huge stakes in Myanmar. Russia and India Report, 23 April. http://indrus.in/articles/2012/04/23/indias huge stakes in myanmar 15552.html (18 November 2012).

Insurgent groups using Myanmar territory: MHA. India Blooms. http://www. indiablooms.com/NewsDetailsPage/2012/newsDetails280812c1. php (26 December 2012).

Myoe, M. A. (2007). Sino-Myanmar economic relations since 1988. Asia Research Institute Working Paper, No. 86. www.ari.nus.edu.sg/ showfile. asp?pubid=647\&type=2 (18 November 2012).

China's ambitions in Myanmar. http://www.asiapacificms.com/articles/ myanmar influence/ (18 November 2012).

Tejada, C . (2012). China not concerned with Obama's visit to Myanmar. The Wall Street Journal, 16 November. http://online.wsj.com/article/SB1000 1424127887324735104578123992776767714.html (18 November 2012).

Meckler, L. (2012). Obama's Asia trip comes amid tug of war with China. The Wall Street Journal, 16 November. http://online.wsj. com/article/SB10001424127887324735104578123360564992242. htmlemod=rss most viewed day asia?mod=WSJAsia article forsub (18 November 2012)

Obama's visit to Myanmar offers a chance to reinforce American influence

in Asia. http://www.cleveland.com/nation/index.ssf/2012/11/ obamas visit to myanmar offers.html (18 November 2012).

Reiffel, L.andSun, Y. (2012).Obamain Burma.BrookingsOpinion. 16November. http://www.brookings.edu/research/opinions/2012/11/16-obamaburma-rieffel-sun (18 November 2012)

China increases defence budget for 2012 by $11.2 \%$ to 670.3 billion Yuan. http://www.sipri.org/media/expert-comments/expl (5 April 2013).

China and India cannot go to war: Lee Kuan Yew. http://www.thehindu. com/news/china-and-india-cannot-go-to-war-lee-kuan-yew/ article1 119062.ece (5 April 2013).

This part of the discussion is entirely drawn from Patwary, Obayedul $\mathrm{H}$. Bangladesh-Myanmar Relations: The Security Dimension. BIPSS Focus.http://www.bipss.org.bd/pdf/Bd Myn rln.pdf (5 April 2013). 
Shyla, Shawon, ASEAN Regional Forum (ARF): What can Bangladesh expect from this security platform? http://www.bipss.org.bd/ images/Focus-ARF(1).pdf (5 April 2013).

Research, Students' Theses, MA in Southeast Asian Studies, Chulalongkorn University. http://www.seachula. com/books.htm

The verdict can be found in http://www.itlos.org/fileadmin/itlos/ documents/cases/case no 16/1-C16 Judgment 1402 2012.pdf (18 November 2012).

Bangladesh dismisses SuU Kyi comments on Rohingya. http:// sg.news.yahoo.com/bangladesh-dismisses-suu-kyi-commentsrohingya-162708166.html (18 November 2012).

Press Release, Dhaka, 18 November 2012, Ministry of Foreign Affairs, Bangladesh. http://mofa.gov.bd/index.php?option=com conten

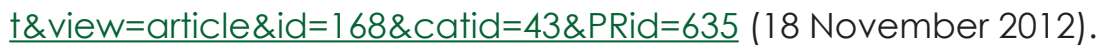

Myanmar-Bangladesh border trade still not active. http://www. elevenmyanmar.com/business/73-myanmar-bangladesh-bordertrade-still-not-active (18 November 2012).

Bangladesh pins hope on Chittagong port. BBC News. http://www.bbc. co.uk/news/business-19462142 (27 December 2012).

Ishtiaque Alam is a graduate of International Relations from Jahangirnagar University, Dhaka, Bangladesh. He served as a Research Analyst at Bangladesh Institute of Peace and Security Studies. He presented papers on counter-terrorism at the national level and has a number of publications to his credit. One of his papers has been accepted by the Centre for Non-Traditional Security Studies of Nanyang Technological University as an e-resource. His papers appeared in Sangam Journal, Journal of International Affairs, Bangladesh defence Journal, Journal of International Relations and Affairs Group, and Foreign Affairs Insights and Reviews. 